\title{
AZ INNOVATÍV KIS- ÉS KÖZÉPVÁLLALKOZÁSOK FINANSZÍROZÁSA KOCKÁZATI TŐKÉVEL - EURÓPAI KIHÍVÁSOK
}

\author{
Dr. Glavanits Judit \\ egyetemi tanársegéd, Széchenyi István Egyetem Deák Ferenc Állam- és Jogtudományi Kar
}

\section{SUMMARY}

Closing the gap between the USA and EU venture capital market size is crutial for european innovative small and medium sized companies. As the financial crises started in 2008 weekend the possibilities for external capital, the role of venture capital financing is revaluated. The study analyses the similarities and differences in the legal rules of venture capital fund raising and financing revised by the USA's Dodd-Frank Act, and the European AIMF-directive. The study also suggest the changes in connection with the European Commission's prepared document on the European Venture Capital Fund, and it's effects on the innovative small-and medium sized companies. The conclusion is that the new rules of venture financing both in the USA and Europe sets up significantly more administrative difficulties for funds, but more stability and safe for entrepreneurs.

Kulcsszavak: kockázati tőke, innováció-finanszírozás, európai kockázati tőkealap

\section{BEVEZETÉS}

Kockázati tőkebefektetések alatt értjük a tőzsdén nem jegyzett, nagy növekedési potenciállal rendelkező gazdasági társaságokban való tulajdonszerzést, amelynek célja a társaság értékének növelése a töke biztosításán túl a társaság vezetésében való részvétel útján, valamint az így megszerzett tulajdoni hányad nagy haszonnal történő értékesítése (Glavanits 2012).

A kockázati tőkebefektetések legaktívabb piacán, az Egyesült Államokban a gazdasági és politikai döntéshozók számára nem kérdés, hogy a kockázati tőkebefektetések az ország teljesítménye szempontjából hasznos, támogatandó gazdasági ügyletek. A National Venture Capital Association 2011 -es évkönyve szerint 2010 során az országban megvalósult 3295 ügylet mintegy 22 milliárd dollár értékü befektetett tökét jelentett, a befektetések értéke az Egyesült Államok GDP-jének mintegy 0,2\%-át érte el (NVCA 2011). Az IHS Global Insight kutatóintézet adatai szerint, 2008-ban a kockázati tőkével érintett vállalatok adták az amerikai adóbevételek $21 \%$-át, 12 millió embert foglalkoztattak, a magánszektor munkavállalóinak 11\%-át (IHS Global Insight 2009). A kockázati tőkével finanszírozott vállalkozások az átlagnál nagyobb árbevétel-növekedést értek el, és a munkaerő-felvétel aránya is magasabb, mint a többi gazdasági szereplö esetében ugyanebben az időszakban. Ez a két faktor nem csak a 2008-as évre jellemző, Josh Lerner 1999-es tanulmánya szintén megerősíti, hogy az (állami) kockázati tőkeprogramokban részt vett, azokon keresztül finanszírozást nyert vállalkozások az átlagosnál szignifikánsan jobb eredményeket érnek el a munkaerő-bővítés és az éves árbevétel tekintetében (Lerner 1999). Az 1970-es évektöl kezdve az Egyesült Államokbeli társaságok közül több, mint 27.000 kapott valamilyen formában kockázati tőkefinanszírozást mintegy 456 milliárd dollár értékben.

Az Európai Unió csak az 1990-es évek végétől foglalkozott aktívan a kockázati tőkepiaccal, illetve annak az európai gazdaságra gyakorolt hatásával. Az EVCA 2008-as évkönyve alapján a kockázati és magántőke finanszírozást kapott mintegy 5200 gazdasági társaság 73,8 milliárd eurónyi tőkéhez jutott. Ezen vállalkozások $85 \%$-a 500 fỏnél kevesebb alkalmazottat foglalkoztató kis- és középvállalkozás volt. A statisztikai adatok szerint 2000 és 2004 között a kockázati tőkével finanszírozott vállalkozások 1 millió új munkahelyet teremtettek az Unióban, amely az érintett munkahelyek esetében évi 5,4\%-os bỏvülést jelent, míg ugyanezen időszak alatt az EU25 átlaga évi $0.7 \%$-os növekedés volt. A kockázati 
tőkefinanszírozást kapott társaságokon belül a növekedési szakaszú vállalkozásoknál a munkaerö-növekedés 2,4\%-os volt 1997 és 2004 között, ugyanakkor a korai fejlődési szakaszú kis- és középvállalkozásoknál évente áltagosan 30,5\%-kal több munkavállalót foglalkoztattak ugyanebben az időszakban (EVCA 2008).

Minthogy a kockázati tőkebefektetések célcsoportja a nagy növekedési potenciállal rendelkező kis- és középvállalkozások (továbbiakban: kkv-k), az Európai Unió mindig is együtt kezelte a kockázati tőkefinanszírozás megítélésének kérdését a kkv-támogatással, az innováció-támogatással. Ebből kifolyólag az európai kockázati tőkepiac elemzése sajátos szemïvegen keresztül látszik az EU-ban, amely a kkv-k könnyebb tőkéhez jutásán keresztül láttatja a piacot. Ugyanakkor az EU munkaanyagai nem nélkülözik a kockázati tőkebefektetések európai eredményeinek elismerését. Külön kiemelésre érdekes, hogy a kockázati töke által finanszírozott innovatív és növekedés-orientált vállalkozások áltagosan kiadásaik 45\%-át fordítják kutatás és fejlesztésre, ami áltagosan évi 3,4 millió eurónak felel meg vállalkozásonként. Ez az tőke hatszor több annál, mint amit az EU-25 kutatás-fejlesztésre legtöbbet fordító 500 vállalkozása költ erre (Európai Bizottság 2007).

Magyarországon a kockázati tőkebefektetések mintegy két évtizedes múltra tekintenek vissza. Karsai Judit szerint a 2000 -es évek végére a kockázati- és magántőkét közvetítő iparág hazánkban - szereplőit, működési mechanizmusát, funkcióját és hatékonyságát tekintve lényegében hasonlóvá vált az európai kockázati- és magántőke ágazathoz (Karsai 2006).

2002 és 2009 között a kockázati töketársaságok 230 ügylet során mintegy 2,2 milliárd eurónyi értékben valósítottak meg befektetéseket magyarországi gazdasági társaságokban (HVCA 2010). Az Európai Unió JEREMIE (Joint European Resources on Micro to Medium Enterprises - JEREMIE) támogatási programja és annak magyar megvalósítás kapcsán várható, hogy a befektetések száma és volumene is szignifikánsan növekedni fog. Ezek az adatok elsősorban a formális, vagyis kifejezetten kockázati tőkefinanszírozás nyújtására létrejött társaságok adatait tartalmazza. Ugyanakkor a piacon jelentős szerepet játszanak az ún. üzleti angyalok, vagy informális befektetők, vagyis azok a magánszemélyek, akik a kockázati tőkebefektetéseket a magánvagyonuk terhére és javára hajtanak végre. A Global Entrepreneurship Monitor (GEM) a vállalkozói aktivitás és gazdasági növekedés kutatási programjában vizsgálta a magyarországi informális tõkebefektetéseket, és arra az eredményre jutott, hogy a felnõtt népesség 2,2\%-a, azaz 144000 magánszemély végzett informális befektetést, átlagosan $1 \mathrm{M}$ Ft értékben (GEM 2004).

Karsai Judit a magyar kockázati tőkepiac általa vizsgált másfél évtizedét 4 fejlődési korszakra osztotta, amelyek közül az utolsót 2001-töl napjainkig jelölte meg, mint a piaci tisztulás, racionalizálás időszaka (Karsai 2008). A tanulmány megjelenése óta lezajlott, 2008tól számított pénzügyi-gazdasági válság azonban véleményem szerint indokolja egy új korszakhatár megjelölését, amely nem csak hazánkban, hanem nemzetközi szinten is megtorpanást jelentett az ágazatban, és még inkább jellemzójévé tette az eltolódást az érett vállalati életszakaszok felé. Ugyanakkor a 2010-es hazai és nemzetközi adatokból már az látszik, hogy a piac ismét magára talál, és új lendületet vesz.

\section{A GAZDASÁgi VÁlság HATÁSA A KOCKẢzATI TỎKEPIAC SZABÁLYOZÁSÁRA}

A 2008-as évhez kötődő pénzügyi és gazdasági válság számos szabályozási kérdést vetett fel világszerte. Természetes reakcióként a jogalkotók a pénzügyi piacok egyes intézményeire, illetve azok egyes szereplöire vonatkozó szabályok gyors újragondolásában látják biztosítva az újabb piaci válság elkerülhetőségét. Ez a jogalkotási dömping megfigyelhető az Egyesült Államokban éppúgy, mint az Európai Unióban.

A kockázati tỏkebefektetések körüli terminológiai bizonytalanság, amelyre a szerző egy korábbi tanulmánya hívja fel a figyelmet (Glavanits 2012), döntő hatással bír egy olyan 
helyzetben, amikor a kockázati tőkealapok és tỏkealap-kezelök piaci elhelyezkedését kell vizsgálni a pénzügyi közvetítỏ rendszerben.

Időpont tekintetében az Egyesült Államok ugyan korábban fogadta el a Wall Street reformjáról és a pénzügyi rendszer átalakításáról szóló Dodd-Frank törvényt, a részletszabályok kidolgozása ugyanakkor éppúgy elhúzódik, mint az Európai Unió által elfogadott, az alternatív befektetési alapkezelőkről szóló irányelv, és az ennek kapcsán módosított szabályok átültetése. Annál is inkább, mivel az EU a teljes jogharmonizációs idöszakot is 2018-ig halasztotta el, de 2 éves átmeneti idő még az európai tagállamoknak is rendelkezésére áll, hogy új szabályaikat elfogadják. A gyorsaság azonban nem feltétlenül jelent minőségi elsöbbséget sem. A két jogforrás összehasonlítása során láthatjuk, hogy mindkét jogalkotó igen hasonló módszerrel, és hasonló eszközökkel látja megvalósíthatónak a pénzügyi szektor befektetési alapkezelöinek megregulázását, illetve azon belül a kockázati tökebefektetéseknek a speciális gazdaságpolitikai szerepét is hasonlóan értékelik.

A kockázati és magántőke-befektetések területén a szabályozás egyértelmü hasonlóságot mutat. Az Egyesült Ällamokban magától értetődő, Európában még mindig magyarázatra szorul, hogy a magántőke-alapok nem elsösorban felelősei a gazdasági válságnak, ugyanakkor az eddigi megengedő szabályozás ezen a területen is szigorításra szorul. Mindkét jogalkotó szembesült a kockázati tőke és a magántőke fogalmának és tevékenysége elkülönítésének problémájával, de a megoldás alapvetően más megközelítést eredményezett.

Az egyik legfontosabb eltérés, hogy míg az Egyesült Államokban a kérdés a kockázati tőkealap meghatározása volt, addig az Unió irányelve mindvégig az alapkezelö megközelítésében vizsgálta a kérdést. Ugyanakkor a változó szabályok az Államokban is végső soron a befektetési tanácsadókra, praktikusan a befektetési alapkezelö menedzsmentjére vonatkoztak.

Az Egyesült Államok szövetségi törvényhozása a SEC-re (Securities and Exchange Commission) hárította azt a feladatot, hogy a szakmai szervezetekkel egyeztetve alkossa meg a „kockázati tőkealap” fogalmát. Maga a tevékenység, ti. a kockázati tökebefektetés, mint ügylet továbbra is tisztázatlan marad, mindössze azok a befektetési társaságok kerülnek definiálásra, akik ezzel a speciális tevékenységgel foglalkoznak. A széles körű társadalmi egyeztetés felszínre hozott számos, korábban csak a szakirodalom által felvetett értelmezési kérdést, és a vélemények sokszínüsége predesztinálta, hogy az elfogadott törvény végül csak bizonyos csoportok elképzeléseit tükrözi vissza. Ennek ellenére igen jelentösnek mondható ez a lépés, hiszen először definiálja részletesen a jogalkotó az intézményi kockázati tökepiac szereplöit. Ezen meghatározás az európai fogalom-meghatározásokhoz képest nem tartalmaz tökekorlátot, ugyanakkor széles körü megkötéseket vezet be az alap által megvalósítható befektetések tekintetében. Ezen belül is az európai szabályozással rokon vonást mutat az a korlátozás, amely a tőkekihelyezést kiegészítő egyéb forrásokra, ezen belül a hitelezésre vonatkozik. A definíció tehát magát az alapot érinti, de a változó előírások az alapkezelöt, vagy befektetési tanácsadót terhelik, számára írnak elö regisztrációs kötelezettséget, vagy adatszolgáltatási kötelezettséget.

Közös elem az amerikai és európai szabályozási módszerben a már müködő alapok tanácsadói, alapkezelői számára biztosított átmeneti idő, illetve kivételes eljárások, amelyekkel az új szabályok alkalmazása elkerülhetö (grandfathering szabályok).

Az Európai Unió jogalkotási mechanizmusában korántsem ilyen egyértelmű az a szándék, hogy a relatíve kis tőkét kezelö, és a pénzügyi kockázatok terén elhanyagolható rizikófaktorral rendelkező kockázati tökealapok kikerüljenek az új, és igen szigorú regisztrációs eljárás alól. Itt már a kezdetektől nem volt szó ezen piaci szegmens kiemeléséről, söt, a kivételként megjelölt befektetési alapkezelői csoport sem egyértelmủen a kockázati tőkeágazat kiemelését célozza, mindössze a de minimis elveket rögzíti. Kétségtelen, hogy ha egy kockázati tőkealap vállalja, hogy tőkeáttétel nélkül finanszíroz vállalkozásokat, akkor a 
legtöbb kockázati tőkealap az 500 millió eurós korlát alá kerül, valamint a célcsoport, vagyis a kis- és középvállalkozások tekintetében a is, (ha a kockázati tökealap valóban a célként megjelölt kkv-szektornak nyújt finanszírozást) kizárólag ilyen társaságokban szerez részesedést, mentesülhet az irányelv rendelkezései alól.

A szabályozások szintén közös jellemzője, hogy a kivételként megfogalmazott társaságok, így a kockázati tőkealapok sem mentesülnek teljes mértékben az új eljárásrend alól. Az Egyesült Államokban a szövetségi kormányzat teljes egészében a SEC-re bízta annak meghatározását, hogy mi az a szolgáltatandó adatmennyiség, amely elegendő ahhoz, hogy az engedélyezési eljárás alól mentesült alapkezelők a pénzügyi rendszerek átláthatóságát ne gátolják. A SEC által hozott elfogadott szabályozás a szakma meglepetésére alig szükítette az éves beszámolók és értesítési kötelezettséggel érintett adatok körét. Az elektronikusan is kitölthetö nyomtatványok (Form $A D V$ ) több mellékletét is folyamatosan vezetni és aktualizálni kell, és az ezekért fizetendö költségtérítés is megegyezik a regisztrációra kötelezett tanácsadókra kirótt összeggel.

Az Európai Unió 61/2011/EU irányelve (AIMF-irányelv) 3. cikk (6)c. pontja alapján az Európai Bizottság fogja megalkotni saját hatáskörében azokat a részletszabályokat, amelyek az irányelv hatálya alá nem tartozó alapkezelök tájékoztatási kötelezettségére vonatkozik.

\section{AZ EURÓPAI KOCKÁZATI TŐKEALAP TERVEZETE}

Az AIMF-irányelv gyakorlati tapasztalata alapján az európai kockázati tőkealap-kezelők 98\%-a nem tartozik az irányelv hatálya alá, mert az általuk kezelt eszközök értéke nem haladja meg az 500 millió EUR-s határt. Ennek praktikus következménye, hogy ezen alapkezelők előtt két választási lehetőség áll: vagy csatlakoznak önként az irányelvhez, és vállalják annak adminisztratív terheit, és egyben élvezik a harmonizált szabályozás elönyeit, vagy a másik lehetőségük, hogy a jelenlegi formájukban tovább müködve, a nemzeti jogrendek hatálya alatt folytatják tevékenységüket.

Ennek a helyzetnek a feloldására szolgál az európai kockázatitőke-alap létrehozása, amely egyszerre teszi lehetővé, hogy a kollektív befektetési vállalkozás élvezze a közös szabályozásból adódó elönyöket, ugyanakkor mentesül az AIMF-irányelvben meghatározott adminisztratív eljárások alól.

A rendelet gyakorlatilag a már meglévő, nemzeti szinten szabályozott kockázati tökealapokon belül egy új, megkülönböztetett kockázati tőkealap-fajtát hoz létre, amely szupranacionális szinten szabályozott, és az Európai Értékpapír Hatóság által vezetett, nyilvános adatbázisban nyilvántartott jogi személy.

A rendelet célja, hogy kizárólag azok a kollektív befektetési vállalkozások használhassák az európai kockázatitőke-alap kifejezést, amelyek a rendelet feltételinek megfelelnek. Ök abban az előnyben részesülnek ezáltal, hogy az Európai Unió székhelyen kívüli tagállamai, mint fogadó államok nem írhatnak elő semmiféle követelményt vagy adminisztratív eljárást a minősített kockázatitöke-alapok forgalmazásával kapcsolatban, valamint nem köthetik a forgalmazást elözetes jóváhagyáshoz (rendelet-tervezet 15 . cikk 2 . pont) Így a bejegyzés székhelyének állama joga alapján bejegyzett, és a rendeletben előírtaknak megfelelően létrehozott európai kockázatitőke-alap és annak kezelője adminisztratív korlátozás nélkül forgalmazhatja eszközeit az Unió területén.

A rendelet által biztosított előnyöket az alábbiak jelentik: A javaslat egységes szabályzatot határoz meg az „európai kockázatitőke-alap” megjelölés alatt müködő alapok forgalmazására vonatkozóan. Az európai kockázatitőke-alapokat három alapvető követelmény határozza meg: (1) A magánbefektetők által vállalt tőke-hozzájárulás 70\%-át kis- és középvállalkozásokba fekteti, (2) ezen kkv-k számára tőkefinanszírozást vagy tőkejellegű finanszírozást nyújt; és (3) nem alkalmaz tőkeáttételt (azaz az alap nem fektet be több tökét annál, mint amennyit a befektetők vállaltak, így nem is adósodik el.) Amennyiben az egész EU-ban gyüjtenek 
forrásokat, a megjelölés alatt müködő alapok mindegyike egységes szabályok és minöségi standardok szerint müködik (ideértve a befektetök tájékoztatásával kapcsolatos standardokat és a müködési követelményeket). Az egységes szabályzat biztosítani tudja azt, hogy a befektetők pontosan tudják, hogy mire számíthatnak, ha európai kockázatitöke-alapba fektetnek.

\section{AZ ÚJ SZABÁlYOZÁS HATÁSA AZ INNOVATÍV VÁLLALKOZÁSOKRA - KÖVETKEZTETÉSEK}

A vállalkozások külső forráshoz jutása nem csak az Európai Unió tagállamaiban, hanem globálisan megoldandó problémaként jelentkezik. A gazdasági és pénzügyi válság egyik következményeként a vállalkozások hitelhez jutási lehetöségei tovább szükültek, igy felértékelődik az olyan alternatív források szerepe, mint amilyen a kockázati tőke.

Megfelelö finanszírozás és vállalati teljesítmény esetén a kockázati töke bevonása relative „drága” forrásnak minősül, ugyanakkor számos esetben a forrásbevonás egyetlen lehetösége is egyben. Az új szabályozási rendszerek ugyan egyszerre rónak adminisztratív terhet a kockázati tökealapokra és azok kezelöire, ugyanakkor az Európai Unió területén kifejezett nyitás figyelhető meg, amennyiben elfogadják az európai kockázati tőkealap tervezetét.

A gazdasági verseny élénkítésében, és az európai kontinens versenyképességének növelésében kulcsszerepet játszó innovatív kis- és középvállalkozások számára a kockázati tökeforrásokhoz való könnyebb hozzáférés feltétlen elönyt jelent akkor, amikor alternatív finanszírozó nincsen a piacon. Az Európai Unió döntéshozói gyakorlatilag 1998 óta törekednek arra, hogy a kockázati tőkepiacot élénkítsék a tagállamokban, ugyanakkor számos adminisztratív korlát, köztük a kettős adóztatás kérdése, a töke szabad áramlásának egyes kérdései korábban akadályozták a befektetők tevékenységét. Az új szabályozás legnagyobb előnye lehet, hogy a vállalkozások több és célzottabb tőkéhez juthatnak hozzá, amely fejlödésüket segítheti.

Közgazdasági kutatások alátámasztották, hogy a tapaszalattal rendelkező, szindikátusba tömörülö kockázati tökebefektetök által megvalósított befektetések nagyobb hozammal rendelkeznek, és a vállalati élettartamot potenciálisan növelik hozzáadott érték képzésével (Brander et al 2002, Lerner 1994, Wright és Locket 2003). Így prognosztizálható, hogy a határon átnyúló kockázati tőke ügyletek növekedésével, és potenciálisan több befektető megjelenésével a kockázati tökepiac élénkül, amely versenyhelyzet a vállalkozások számára is elönnyel jár a befektetői tárgyalások során (Wang és Wang 2009).

\section{FELHASZNÁLT IRODALOM}

Jogforrások:

Az Európai Parlament és a Tanács 2004/39/EK irányelve a pénzügyi eszközök piacairól. HL 2004.4.30. L 145/1.

$\operatorname{COM}(2007) 853$ végleges A Bizottság közleménye a Tanácsnak, az Európai Parlamentnek, az Európai Gazdasági és Szociális Bizottságnak és a Régiók Bizottságának a kockázati tőkealapok határokon átívelő befektetéseit korlátozó akadályok felszámolásáról.

Dodd-Frank Wall Street Reform and Consumer Protection Act, Pub.L. 111-203, H.R. 4173.

SECURITIES AND EXCHANGE COMMISSION, 17 CFR Part 275, Release No. IA-3222; File No. S7-37-10, RIN 3235-AK81

Code of Federal Regulations, Part 275 - Rules and Regulations, Investment Advisers Act of 1940. § 275.203(1)-1

COM(2011) 669. Európai Bizottság: A stabilitás és növekedés menetrendje. Az Európai Parlament és a 2011/61/EU irányelve az alternatív befektetésialap-kezelökröl 
COM(2011) 860. Európai Bizottság: Javaslat Az Európai Parlament és a Tanács rendelete az európai kockázati tőkealapokról.

\section{Szakirodalom:}

Brander, J. A. - R. Amit - W. Antweiler (2002): Venture-Capital Syndication: Improved Venture Selection vs. The Value-Added Hypothesis. Journal of Economics \& Management Strategy, 2002/11, 423-452.0.

EVCA Yearbook 2011 (2012). Pan-European Private Equity \& Venture Capital Activity Report. EVCA, Brüsszel.

GEM Hungary (2004): (szerk. Szerb László) Vállalkozásindítás, vállalkozói hajlandóság és a vállalkozási kömyzeti tẻnyezök alakulása Magyarországon a 2000-es évek első felében.

Glavanits J. (2012): A kockázati tökebefektetések jogi fogalmának meghatározása. JogÁllam-Politika, 2012/1. 109-123.o.

HVCA Évkönyv (2010). Letölthető az Egyesület honlapjáról www.hvca.hu (2011.12.20)

IHS Global Insight (2009): Venture impact. The economic importance of venture capital backed companies to the U.S. economy. Fifth edition. 2009. Letölthetö: http://www.altassets.net/pdfs/nvca_venture_impact 5thedition.pdf (2011. június 10.)

Karsai J. (2006): A magyarországi kockázatitőke-finanszírozás másfél évtizede (1989-2004) In: Makra Zsolt (szerk) A kockázati töke világa. Aula, 33-52.o.

Karsai J. (2008): „Az aranykor vége”. A kockázati- és magántőke-ágazat fejlődése Közép- és Kelet-Európában. MTA Közgazdaságtudományi Intézet, Mühelytanulmány. Budapest.

Lerner, J. (1994): The syndication of venture capital investments. Financial Management. 23. 16-27.0.

Lerner, J. (1999): The Government as Venture Capitalist: The Long-Run Impactof the SBIR Program. Journal of Business. 1999. Vol. 72. 285-318.o

NVCA Yearbook (2011) Letölthető az egyesület honlapjáról. www.nvca.org (2011. 12.10.) Wright, M. - A. Locket (2003): The Structure and Management of Alliances: Syndication in the Venture Capital Industry. Journal of Management Studies, 40. szám, 2073-2102.o.

Wang, L.- .Wang (2009): Syndication as a Management Strategy. In: M. Bergmann - T. Faust (szerk) Handbook of Business and Finance. Nova Science Publishers, Inc., 